\title{
Хірургічні аспекти лікування тотального варикотромбофлебіту великої підшкірної вени
}

\author{
Мета роботи: обгрунтувати показання до хірургічного лікування тотального варикотромбофлебіту в басейні великої підшкірної \\ вени (ВПВ). \\ Матеріали і методи. У роботі наведено аналіз результатів обстеження та лікування 27 хворих із тотальним варикотромбофлебітом \\ у басейні великої підшкірної вени. \\ Результати досліджень та їх обговорення. У 24 (88,9 \%) пацієнтів верхівка тромботичних мас локалізувалася у верхній \\ третині стегна в середньому на $(5,2 \pm 1,4)$ см від сафенофеморального співгирла. У $3(11,1$ \%) хворих верхівка тромботичних \\ мас доходила до остіального клапана, але не переходила через сафенофеморальне співгирло. Нижня межа тромботичного \\ ураження у 4 (14,8 \%) хворих локалізувалася у верхній, у 16 (59,3 \%) - у середній та у 7 (25,9 \%) - у нижній третинах гомілки. \\ У 22 (81,5 \%) пацієнтів у патологічний процес, крім магістрального стовбура, залучалися притоки ВПВ. У 21 (95,5\%) пацієнта \\ з тромботичним ураженням приток ВПВ спостерігали їх варикозну трансформацію. \\ Операційне втручання обов’язково включало кросектомію, видалення тромбованого стовбура ВПВ та при потребі тромбованих \\ приток, субфасціальне лігування неспроможних вен. При відсутності варикозних змін та неспроможних пронизних вен об'єм \\ операційного втручання скорочували за рахунок флебоцентезу з наступною склерооблітерацією. Активна хірургічна тактика \\ при тотальному варикотромбофлебіті дала можливість ефективно запобігти розвитку венозних тромбоемболічних ускладнень.
}

Ключові слова: тотальний варикотромбофлебіт; велика підшкірна вена; склерооблітерація; флебоцентез; кросектомія.

Постановка проблеми і аналіз останніх досліджень та публікацій. Дискусія щодо вибору методу та способу лікування хворих із поверхневим тромбофлебітом: амбулаторного чи стаціонарного, консервативного або оперативного, термінового або планового, одномоментного або етапного постійно триває. Зарубіжні фахівці віддають перевагу консервативному лікуванню, операцію виконують тільки у поодиноких хворих $[2,5]$. Кількість прихильників переважно консервативного ведення пацієнтів із варикотромбофлебітом поступово зростає. Методи лікування тромбофлебіту варіюють від еластичної компресії та застосування нестероїдних протизапальних засобів до хірургічного лікування з високим перев'язуванням великої (ВПВ)/малої підшкірної вени ноги з стрипінгом або без нього; з призначенням антикоагулянтів або без такого [4].

Водночас у третини пацієнтів із варикотромбофлебітом у великій підшкірній вені тромботичний процес досягає гирла, що становить реальну загрозу здоров’ю та життю пацієнта. В літератуpi $є$ підтверджені дані, що тромб може наростати за добу до 20-35 см, верхня межа тромботичного ураження, як правило, на 10-20 см вище клінічної, а момент переходу тромботичного процесу на глибокі вени прихований та клінічно не проявляється $[3,5]$. При цьому у кожного другого неоперованого пацієнта $з$ варикотромбофлебітом діа- гностують симптоми тромбоемболії легеневої артерії (ТЕЛА) [1, 4, 5].

Таким чином, навіть реальна загроза тромбозу глибоких вен та тромбоемболії легеневої артерії не знімає дискусії щодо вибору методу лікування хворих із варикотромбофлебітом великої підшкірної вени. Широкий медичний загал йде шляхом найменшого спротиву, а саме безапеляційного призначення антикоагулятної терапії, тоді як тотальний варикотромбофлебіт великої підшкірної вени найчастіше призводить до венозних тромбоемболічних ускладнень, а їхня частота невпинно зростає незважаючи на застосування сучасних антикоагулянтних засобів.

Мета роботи: обгрунтувати показання до хірургічного лікування тотального варикотромбофлебіту в басейні великої підшкірної вени.

Матеріали і методи. В роботі проаналізовано результати обстеження та хірургічного лікування 27 пацієнтів із тотальним варикотромбофлебітом у басейні великої підшкірної вени, з них чоловіків було 8 (29,6 \%) та 19 (70,4 \%) жінок. Вік хворих становив від 21 до 78 років, середній вік $(49 \pm 2,3)$ року.

До тотального варикотромбофлебіту відносили протяжний тромбоз варикозно зміненого магістрального стовбуру із одночасним захопленням стегнового та гомілкового сегментів ВПВ. 
Для обстеження хворих застосували лабораторні методи дослідження, а також інструментальні: ультразвукову доплерографію та ультразвукове дуплексне сканування (“ULTIMA PRO-30, z.one Ultra”, ZONARE Medical Systems Inc., CШA).

Результати досліджень та їх обговорення. Основна небезпека тотального варикотромбофлебіту ВПВ - це трансфасціальний тромбоз, тобто перехід тромботичного процесу на глибоку венозну систему через сафенофеморальне співгирло.

Під час ультразвукового дослідження вен нижньої кінцівки особливу увагу звертали на поширення тромботичного процесу в поверхневих венах, визначали верхню та нижню межі тромботичного процесу, інтактність глибокої венозної системи та стан пронизних вен. У 24 (88,9 \%) пацієнтів верхівка тромботичних мас локалізувалася у верхній третині стегна в середньому на $(5,2 \pm 1,4)$ см від сафенофеморального співгирла. У 3 (11,1 \%) хворих верхівка тромботичних мас доходила до остіального клапану, але не переходила через сафенофеморальне співгирло. Нижня межа тромботичного ураження у 4 (14,8 \%) хворих локалізувалася у верхній, у 16 (59,3 \%) - у середній та у 7 (25,9 \%) - у нижній третинах гомілки. У 22 (81,5 \%) пацієнтів у патологічний процес, крім магістрального стовбура, залучалися притоки ВПВ. При цьому тромботичне ураження однієї притоки ВПВ спостерігали у 17 (77,3 \%) пацієнтів, двох у 3 (13,6 \%) та трьох - у 2 (9,1 \%) пацієнтів. Найчастіше тромботичний процес у 15 (55,6 \%) пацієнтів захоплював вену Леонардо, яка у 6 (40 \%) хворих сполучалася з глибокою венозною системою за допомогою неспроможних пронизних вен. Крім того, спостерігали тромботичне ураження таких приток ВПВ:

- медіальна додаткова гілка ВПВ - 5;

- латеральна додаткова гілка ВПВ - 3;

- медіальна міжсафенна вена - 8 випадків.

У 21 (95,5 \%) пацієнтів із тромботичним ураженням приток ВПВ спостерігали їх варикозну трансформацію.

У 2 пацієнтів із тотальним варикотромбофлебітом ВПВ виявили неспроможні пронизні вени у нижній-середній третинах стегна, які сполучали ВПВ із поверхневою стегновою веною.

Незважаючи на весь спектр антикоагулянтної терапії єдиною можливістю ліквідувати загрозу венозних тромбоемболічних ускладнень $є$ операційне втручання. Крім того, видалення варикозно трансформаних поверхневих вен запобігає рецидиву варикотромбофлебіту та прогресуванню хронічної венозної недостатності.
Операційне втручання розпочинали з кросектомії. У пацієнтів із верхівкою тромботичних мас у гирлі ВПВ обробку останнього, з метою запобігання фрагментації тромба, проводили після відкритої тромбектомії з венотомного розрізу термінального відділу ВПВ (рис. 1). Наступним етапом виконували видалення тромбованого стовбура ВПВ, тобто довгий стрипінг. ВПВ при тотальному варикотромбофлебіті, з метою запобігання рецидиву тромбозу, видаляли на всьому протязі незалежно від нижнього рівня тромботичного ураження. Видалення магістралі проводили у два етапи: спочатку на стегновий, а потім - гомілковий сегменти. Зважаючи на варикозну трансформацію стовбура ВПВ, тромботичну оклюзію та запальні зміни венозної стінки венекстрактор для венектомії вдалося використати у лише 8 (29,6 \%) пацієнтів. У 19 (70,4 \%) хворих видалення стовбура ВПВ проводили з окремих розрізів. Крім того, у 2 пацієнтів наявність неспроможних пронизних вен у нижній-середній третині стегна вважали абсолютним протипоказанням до венекстракції. Видалення стегнового сегмента ВПВ проводили з окремих розрізів після субфасціального лігування неспроможної вени.

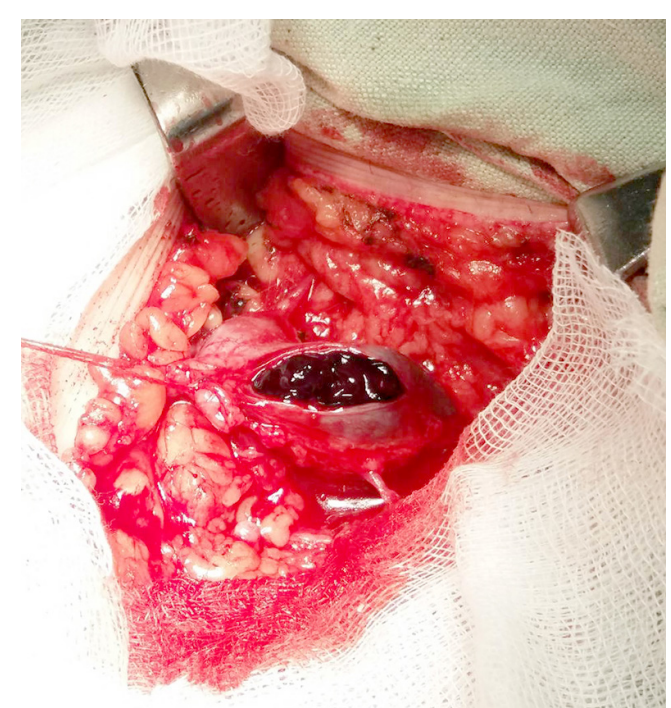

Рис. 1. Інтраопераційне фото: венотомний розріз тромбованого гирла великої підшкірної вени.

У 4 із 23 пацієнтів із локалізацією нижньої межі тромботичного ураженні в середній-нижній третинах гомілки після видаленння стегнового сегмента ВПВ виконали флебоцентез із наступною стовбуровою склерооблітерацією (рис. 2). Показанням до флебоцентезу слугували відсутність варикозних змін венозної стінки. 


\section{З ДОСВІДУ РОБОТИ}

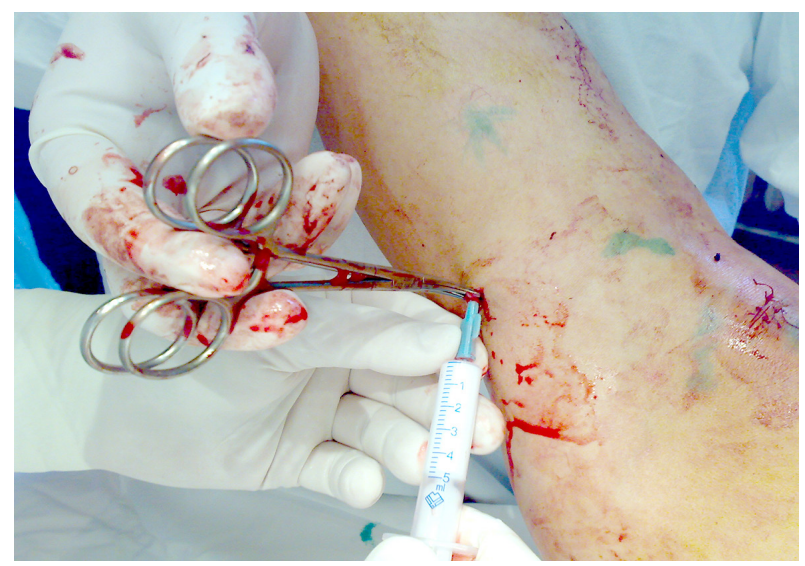

Рис. 2. Інтраопераційне фото: стовбурова склерооблітерація на гомілці.

Найбільшого значення надавали тромботичній оклюзії вени Леонардо внаслідок небезпеки поширення тромботичного ураження через неспроможні пронизні вени на глибоку венозну систему. Через це при даній локалізації притокового варикотромбофлебіту вважали недоцільним виконувати флебоцентез. У всіх пацієнтів із варикотромбофлебітом вени Леонардо виконали видалення останньої з окремих мініфлебектомічних доступів після субфасціального лігування неспроможних пронизних вен.

У 12 випадках тромботичного ураження інших приток ВПВ виконали такі втручання: видалення варикозно зміненої тромбованої притоки ВПВ з окремих розрізів $(\mathrm{n}=7)$ та флебоцентез, склерооблітерацію притоки ( $\mathrm{n}=5)$.

У післяопераційному періоді всім пацієнтам, крім антибактеріальної профілактики, признача-

\section{СПИСОК ЛІТЕРАТУРИ}

1. Патологоанатомічна характеристика ускладненої гострої хірургічної судинної патології, поєднаної з соматичними захворюваннями / Боднар П. Я., Трач Росоловська С. В., Миколенко А. 3. // Шпитальна хірургія. Журнал імені Л. Я. Ковальчука. - 2014. - № 1. - С. 79-81. DOI: https://doi. org/10.11603/1681-2778.2014.1.4426

2. European guidelines on perioperative venous thromboembolism prophylaxis: surgery in the elderly / S. Kozek-Langenecker, C. Fenger-Eriksen, E. Thienpont, G. Barauskas // European Journal of Anaesthesiology (EJA). - 2018. - Vol. 35 (2). - P. 116- ли оральні антикоагулянти терміном до 1 місяця, флеботропні препарати та еластичну компресію терміном до 2-3 місяців.

Періопераційно у жодного пацієнта не спостерігали венозних тромбоемболічних ускладнень. Впродовж одного року спостереження в жодного з прооперованих пацієнтів не спостерігали рецидиву варикозної хвороби та варикотромбофлебіту.

Таким чином, активний хірургічний підхід при тотальному варикотромбофлебіті великої підшкірної вени дає можливість ефективно запобігти розвитку тромбозу глибоких вен та венозних тромбоемболічних ускладнень, ліквідує патологічний запальний процес у варикозно трансформованих венах, що дає можливість у майбутньому запобігти прогресуванню хронічної венозної недостатності.

Висновки. 1. При гострому тотальному варикотромбофлебіті великої підшкірної вени об’єм операційного втручання повинен бути розширений за рахунок адекватної кросектомії та повного видалення магістрального стовбура.

2. При локалізації верхівки тромботичних мас у гирлі великої підшкірної вени кросектомію слід проводити після відкритої тромбектомії з венотомного розрізу термінального відділу останньої.

3. Тромботичний процес у притоках великої підшкірної вени повинен слугувати показанням до усунення патологічного процесу в останніх 3 метою ліквідації загрози поширення тромбозу на пронизні вени гомілки та стегна.

4. Зменшення об'єму та травматичності операційного втручання при тотальному тромбофлебіті забезпечують за рахунок використання флебоцентезу з наступною склерооблітерацією при умові відсутності неспроможних пронизних вен.

122. DOI: 10.1097/EJA.0000000000000705.

3. Профілактика тромбоемболічних ускладнень при трансфасціальному тромбозі нижніх кінцівок / Русин В. I., Корсак В. В., Попович Я. М. [та ін. ] // Клінічна хірургія. - 2016. - № 12. - С. 29-31.

4. Коваленко В. Н. Руководство по кардиологии / В. Н. Коваленко. - Київ : МОРИОН, 2008. - 850 - 892.

5. Хірургічне лікування тромбозів нижньої порожнистої вени : монографія / Русин В. І., Корсак В. В., Попович Я. М. [та ін. ]. - Ужгород : Карпати, 2017. - 360 с. + 76 с. вкл.

\section{REFERENCES}

1. Bodnar, P.Ya., Trach Rosolovska, S.V., \& Mykolenko, A.Z. (2014). Patolohoanatomichna kharakterystyka uskladnenoi hostroi khirurhichnoi sudynnoi patolohii, poiednanoi z soma-

tychnymy zakhvoriuvanniamy [Pathomorthological characteristics of complicated surgical acute vascular pathology combined with somatic diseases]. Shpytalna khirurhiia. Zhurnal imeni 
L.Ya. Kovalchuka - Hospital Surgery. Journal named after L. Ya. Kovalchuk, 65 (1), 79-81. DOI: https://doi.org/10.11603/16812778.2014.1.4426 [in Ukrainian].

2. Kozek-Langenecker, S., Fenger-Eriksen, C., Thienpont, E., \& Barauskas, G. (2018). European guidelines on perioperative venous thromboembolism prophylaxis: surgery in the elderly. European Journal of Anaesthesiology (EJA), 35(2), 116-122. DOI: 10.1097/EJA.0000000000000705

3. Rusyn, V.I., Korsak, V.V., Popovych, Ya.M., Boldizhar, P.O., \& Kochmar O.M. (2016). Profilaktyka uskladnen pry transfatsialnomu trombozi nyzhnikh kintsivok [Prophylaxis of thromboembolic complications in transfascial thrombosis of the lower extremities]. Klinichna khirurhiia - Clinical Surgery, (12), 29-31 [in Ukrainian].

4. Kovalenko, V.N. (2008). Rukovodstvo po kardiologii [Cardiology guide]. Kyiv: MORION [in Russian].

5. Rusyn, V.I., Korsak, V.V., \& Popovych, Ya.M. (2017). Khirurhichne likuvannia tromboziv nyzhnoi porozhnystoi veny: monohrafiia [Surgical treatment of inferior vena cava thrombosis: a monograph]. Uzhhorod: Karpaty [in Ukrainian].

Отримано 12.01.2021

\author{
S. S. FILIP, V. V. RUSYN, I. I. HADZHEHA
}

Uzhhorod National University

\title{
SURGICAL ASPECTS OF TREATMENT OF TOTAL VARICOTHROMBOPHLEBITIS OF THE GREAT SUBCUTANEOUS VEIN
}

\begin{abstract}
The aim of the work: to justify the indications for surgical treatment of total varicothrombophlebitis in the basin of the great saphenous vein. Materials and Methods. The analysis of the results of examination and treatment of 27 patients with total varicothrombophlebitis in the basin of the great saphenous vein is presented.

Results and Discussion. In 24 (88.9 \%) patients, the apex of thrombotic masses was localized in the upper third of the thigh by an average of $(5.2 \pm 1.4) \mathrm{cm}$ from the saphenofemoral cotyledon. In $3(11.1 \%)$ patients, the apex of thrombotic masses reached the ostial valve, but did not pass through the saphenofemoral cotyledon. The lower limit of thrombotic lesions in 4 (14.8\%) patients was localized in the upper, in 16 (59.3 \%) - in the middle and in 7 (25.9\%) - in the lower thirds of the leg. In 22 (81.5 \%) patients, in addition to the main trunk, the tributaries of VTP were involved in the pathological process. Varicose veins were observed in 21 (95.5 \%) patients with thrombotic lesions.

Surgery necessarily included a crossectomy, removal of the thrombosed trunk of the VTP and, if necessary, thrombosed inflows, subfascial ligation of failed veins. In the absence of varicose veins and failed penetrating veins, the volume of surgery was reduced by phlebocentesis followed by scleroobliteration. Active surgical tactics for total varicothrombophlebitis have effectively prevented the development of venous thromboembolic complications.
\end{abstract}

Key words: total varicothrombophlebitis; great saphenous vein; scleroobliteration; phlebocentesis; crossectomy.

С. С. ФИЛИП, В. В. РУСИН, И. И. ГАДЖЕГА

Ужгородский национальный университет, Ужгород

\section{ХИРУРГИЧЕСКИЕ АСПЕКТЫ ЛЕЧЕНИЯ ТОТАЛЬНОГО ВАРИКОТРОМБОФЛЕБИТА БОЛЬНОЙ ПОДКОЖНОЙ ВЕНЫ}

Цель работы: обосновать показания к хирургическому лечению тотального варикотромбофлебита в бассейне большой подкожной вены (БПВ).

Материалы и методы. В работе приведен анализ результатов обследования и лечения 27 больных с тотальным варикотромбофлебитом в бассейне большой подкожной вены.

Результаты исследований и их обсуждение. В 24 (88,9 \%) пациентов верхушка тромботических масс локализовалась в верхней трети бедра в среднем на $(5,2 \pm 1,4)$ см от сафенофеморальное соустья. В $3(11,1 \%)$ больных верхушка тромботических масс доходила до остиального клапана, но не переходила через сафенофеморальное соустье. Нижняя граница тромботического поражения в 4 (14,8 \%) больных локализовалась в верхней, у 16 (59,3 \%) - в средней и у 7 (25,9 \%) - в нижней третях голени. В 22 (81,5 \%) пациентов в патологический процесс, кроме магистрального ствола, вовлекались притоки БПВ. В 21 (95,5\%) пациента с тромботической поражением приток БПВ наблюдали их варикозную трансформацию.

Операционное вмешательство обязательно включало кроссэктомия, удаление тромбированного ствола БПВ и при необходимости тромбированных приток, субфасциальное лигирование несостоятельных вен. При отсутствии варикозных изменений и несостоятельных пронизних вен объем операционного вмешательства сокращали за счет флебоцэнтеза с последующей склерооблитерацией. Активная хирургическая тактика при тотальном варикотромбофлебите дала возможность эффективно предотвратить развитие венозных тромбоэмболических осложнений.

Ключевые слова: тотальный варикотромбофлебит; большая подкожная вена; склерооблитерация; флебоцентез; кроссэктомия. 